\title{
Effect of Nitrogen Fertilization and Residue Management Practices on Ammonia Emissions from Subtropical Sugarcane Production
}

\author{
Sanku Datta Mudi ${ }^{1}$, Jim J. Wang ${ }^{1 *}$, Syam Kumar Dodla ${ }^{1,2}$, Allen Arceneaux ${ }^{1}$, and H.P. Viator ${ }^{3}$ \\ ${ }^{1}$ School of Plant, Environmental and Soil Sciences, Louisiana State University Agricultural \\ Center, Baton Rouge, LA 70803, USA \\ ${ }^{2}$ Red River Research Station, Louisiana State University Agricultural Center, Bossier City, LA \\ 71112, USA \\ ${ }^{3}$ Iberia Research Station, Louisiana State University Agricultural Center, Jeanerette, LA 70544, \\ USA
}

\section{*Corresponding Author:}

Jim J. Wang

School of Plant, Environmental and Soil Sciences

Louisiana State University Agricultural Center, Baton Rouge, LA, 70803, USA

Email: JJWang@agcenter.lsu.edu

Phone: (225) 578-1360

Keywords: Ammonia emission factor, Sugarcane, Urea, UAN, Residue management, Air quality 


\section{ABSTRACT}

Ammonia $\left(\mathrm{NH}_{3}\right)$ emission from soil is a loss of nitrogen $(\mathrm{N})$ nutrient for plant production as well as an issue of air quality, due to the fact that it is an active precursor of airborne particulate matters. Ammonia also acts as a secondary source of nitrous oxide $\left(\mathrm{N}_{2} \mathrm{O}\right)$ emission when present in the soil. In this study, the impacts of different sources of $\mathrm{N}$ fertilizers and harvest residue management schemes on $\mathrm{NH}_{3}$ emissions from sugarcane production were evaluated based on an active chamber method. The field experiment plots consisting of two sources of $\mathrm{N}$ fertilizer (urea and urea ammonium nitrate (UAN)) and two common residue management practices, namely residue retained (RR) and residue burned (RB), were established on a Commerce silt loam. The $\mathrm{NH}_{3}$ volatilized following $\mathrm{N}$ fertilizer application was collected in an impinger containing diluted citric acid and was subsequently analyzed using ion chromatography. The $\mathrm{NH}_{3}$ loss was primarily found within 3-4 weeks after $\mathrm{N}$ application. Average seasonal soil $\mathrm{NH}_{3}$ flux was significantly greater in urea plots with $\mathrm{NH}_{3}-\mathrm{N}$ emission factor $(\mathrm{EF})$ twice or more than in UAN plots $(2.4-5.6 \%$ vs. $1.2-1.7 \%)$. The RR residue management scheme had much higher $\mathrm{NH}_{3}$ volatilization than the RB treatment regardless of $\mathrm{N}$ fertilizer sources, corresponding to generally higher soil moisture levels in the former. Ammonia- $\mathrm{N}$ emissions in $\mathrm{N}$ fertilizer-treated sugarcane fields increased with increasing soil water-filled pore space (WFPS) up to $45-55 \%$ observed in the field. Both $\mathrm{N}$ fertilizer sources and residue management approaches significantly affected $\mathrm{NH}_{3}$ emissions. 


\section{INTRODUCTION}

Gaseous ammonia $\left(\mathrm{NH}_{3}\right)$ emission following $\mathrm{N}$ fertilization is one of the major pathways of nitrogen $(\mathrm{N})$ loss from a soil profile which leads to the reduction in $\mathrm{N}$ use efficiency by plants. It plays an important role in atmospheric chemistry by neutralizing precipitation and aerosol formation (Anderson et al., 2003; Behera et al., 2013). Ammonia itself is not considered a major air pollutant according to the Clean Air Act (CAA), but it acts as an active precursor of $\mathrm{PM}_{2.5}$ formation in the air and a secondary source for nitrous oxide $\left(\mathrm{N}_{2} \mathrm{O}\right)$ emissions when present in the soil. Under typical atmospheric conditions, $\mathrm{NH}_{3}$ reacts with gaseous sulfur dioxide $\left(\mathrm{SO}_{2}\right)$ and oxides of nitrogen $\left(\mathrm{NO}_{\mathrm{x}}\right)$ to form secondary fine and ultrafine particles like ammonium sulfate $\left[\left(\mathrm{NH}_{4}\right)_{2} \mathrm{SO}_{4}\right]$ and ammonium nitrate $\left[\mathrm{NH}_{4} \mathrm{NO}_{3}\right]$, which are highly responsible for different human health issues, especially respiratory problems (Seinfeld and Pandis, 1998; Anderson et al., 2003). It has been reported that ammonium sulfates contribute more than $40 \%$ of the total $\mathrm{PM}_{2.5}$ of the southeastern part of the United States (USEPA, 2014). In addition, sulfate and nitrate aerosols can influence global radiation budget by acting as cloud condensation nuclei $(\mathrm{CCN})$ and scattering incoming solar radiation (Bauer et al., 2007; Myhre et al., 2009; Behera et al., 2013)

Major sources of $\mathrm{NH}_{3}$ emission include livestock production, fertilizer application; human and animal waste, biomass burning, and soil biogenic processes (Bouwman et al., 1997; Wu et al., 2008). Agricultural application of synthetic fertilizers can contribute about 12 to $16 \%$ of the total global atmospheric $\mathrm{NH}_{3}$ emissions (Pain et al., 1998; Stephen and Aneja, 2008). Although there have been emission factors (EFs) of $\mathrm{NH}_{3}$ from agricultural uses of $\mathrm{N}$ fertilizers in the past, many current available EFs did not consider specific agricultural production systems and contained various inaccuracies (Goebes et al., 2003). The magnitude of $\mathrm{NH}_{3}$ emissions from $\mathrm{N}$ fertilizers is influenced by various factors including type and quantity of fertilizers used, timing 
and techniques of fertilizer application, soil moisture content as well as other soil \& meteorological conditions. The majority of $\mathrm{NH}_{3}$ emissions from agricultural fields usually occur within a few days of fertilizer application (Ruijter et al., 2010; Turner et al., 2012; Tian et al., 2015). However, the accurate measurement of atmospheric $\mathrm{NH}_{3}$ concentration is often very difficult due to the fact that $\mathrm{NH}_{3}$ is a sticky gas and can easily be adsorbed by almost all surfaces (Anderson et al., 2003; Behera et al., 2013). In addition, under particular inorganic aerosol system (such as ammonium-sulfate-nitrate-water), nitrate and sulfate compete for available $\mathrm{NH}_{3}$. At sulfate concentration of $>9 \mu \mathrm{g} \mathrm{m}^{-3}$, ammonium-nitrate aerosol concentration was found to be near zero (West et al. 1999). Therefore, understanding $\mathrm{NH}_{3}$ emission from different agricultural production systems is very important for assessing the impact of management practices on potential air quality in that region.

Sugarcane is one of the major row crops grown in many parts of the world. In the mainland U.S., sugarcane production is concentrated in Louisiana, Florida, and Texas. Sugarcane produces large biomass and requires significant amounts of nutrients especially $\mathrm{N}$ and $\mathrm{K}$ and special land management practices (Fageria et al., 1997; Franca et al., 2012). Solid urea has traditionally been used for agricultural crop production but application of liquid urea ammonium nitrate (UAN) is increasingly becoming popular especially in southern USA for sugarcane production in recent years. This change in $\mathrm{N}$ fertilizer source likely has different effects on $\mathrm{NH}_{3}$ loss dynamics and subsequently the air quality.

Field management of sugarcane residues also varies widely across the globe. For instance, in Australia, sugarcane harvest residues (trash) are generally kept as such in the field to conserve soil moisture needed for better ratoon production (Wood, 1991; Fageria et al., 1997), whereas, in-situ biomass burning of the sugarcane residues is a common practice in Brazil and major parts 
of the U.S. (Franca et al., 2012). Two open-field burnings of sugarcane residues are often carried out in U.S. sugarcane production, before-harvest burning of standing cane and after-harvest ground burning of combine residue. The former is to eliminate leafy trash for easy combining (cutting) and sugar milling processing, whereas the latter is to prevent the yield loss of subsequent ratoon crops if the residue is not removed (Viator et al., 2008, 2009a,b, Udeigwe et al., 2010). The latter is especially true in subtropical sugarcane production, such as in Louisiana, due to negative soil water-temperature relations of relatively cold and wet winter, production of allelochemicals, and high populations of overwintering sugarcane borers and sugarcane beetles (Richard, 2001; Kennedy and Arceneaux, 2006; Viator et al., 2008). Although sweeping residue after combine harvesting has recently been suggested as an alternative solution to this issue, the limited harvest time window in a wet winter, especially for the late-harvested plant cane and first stubble cane crops, makes such an option difficult to be realized (Viator et al., 2009b). An approximate $38 \%$ of the sugarcane crop area was burned during 2013 in the US (USEPA, 2015). While various studies have investigated impacts of residue retention on runoff water quality (Southwick et al., 2001; Viator et al., 2009a; Udeigwe et al., 2010), there has been very little information concerning the effect of these sugarcane residue management practices on ammonia emission from soil, an important factor that has both $\mathrm{N}$ efficiency and air quality implications. Few studies have focused on other crops under different climate regions (Hutchings et al., 2001; Hyde et al., 2003; Gong et al., 2013; Yang et al., 2015; Zhang et al., 2011; Bosch-Serra et al., 2014). Therefore, the goal of this study was to evaluate the emission losses of ammoniacal $\mathrm{N}$ from sugarcane production as impacted by two common $\mathrm{N}$ fertilizer sources (urea and UAN) and two residue management practices (residue retained, RR and residue burn, RB) in the subtropical region of southern U.S.A. 


\section{MATERIALS AND METHODS}

\subsection{Site location and characteristics}

The field experiments were carried out at the Louisiana State University AgCenter St. Gabriel research station (USA, $30^{\circ} 15^{\prime} 13^{\prime \prime} \mathrm{N} 91^{\circ} 6^{\prime} 5^{\prime \prime} \mathrm{W}$ ) in 2012 and 2013 . First year and second year stubble sugarcane (Saccharum officinarum) was used as the planting material for 2012 and 2013, respectively. The soil of the experimental site was a commerce silt loam (Fine-silty, mixed, superactive, nonacid, thermic Fluvaquentic Endoaquepts). Surface soil samples (15 cm depth) from the site were taken before the field experiment and analyzed for particle size distribution, cation exchange capacity (CEC), $\mathrm{pH}$, electrical conductivity (EC), total $\mathrm{N}$, total $\mathrm{C}$ and different nutrients (P, K, Ca, Mg, and S). Physical and chemical characteristics of the background soil of the field experiment are presented in Table 1.

Additional soil samples were also collected throughout the seasons in both 2012 and 2013 to determine water filled pore space (WFPS) during gas sampling for measuring $\mathrm{NH}_{3}$ fluxes. The WFPS in percentage was calculated using the formula:

$$
\Psi=(\Phi \mathrm{V} / \mathrm{TP})^{*} 100
$$

Where $\Psi$ is the WFPS (\%), $\Phi_{\mathrm{V}}$ is the volumetric water content (\%) and TP is the total porosity $(\%)$ of the soil.

\subsection{Fertilizer treatments and residue managements}

Field experiments consisting of 6 treatments (one control, two N sources, and two residue management approaches; 3x2=6) were established in 2012. For two $\mathrm{N}$ fertilizer source treatments, it was applied at the rate of $135 \mathrm{~kg} \mathrm{~N} \mathrm{ha}^{-1}$ in the form of granular urea $(45.9 \% \mathrm{~N})$ and 
liquid urea ammonium nitrate (UAN; $31.9 \% \mathrm{~N}$ ). The control plots (no $\mathrm{N}$ was added) were used to obtain the background $\mathrm{NH}_{3}$ concentration. Urea was surface broadcasted followed with soil cover and UAN was injected directly into the soil through applicator and worked into the shoulders of the rows. Two different types of residue management schemes including the residue burned (RB) treatment (harvested sugarcane trash was burned in the field) and the residue retained $(\mathrm{RR})$ treatment (residue from the previous sugarcane harvest was left as such on the soil surface) were implemented. In 2013, separate field experiments were conducted to evaluate the effects of fertilizers and residue management separately on $\mathrm{NH}_{3}$ volatilization. Experiments of $\mathrm{N}$ fertilizer source comparisons were conducted in the more commonly RB residue management plots, whereas residue management approaches were compared in the more popular UAN fertilized plots. In both cases, $\mathrm{N}$ fertilizer was applied at a rate of $157 \mathrm{~kg} \mathrm{~N} \mathrm{ha}^{-1}$ due to the second stubble of the ratoon crop. In both years, randomized complete block design (RCBD) was used for the evaluation. Fertilizers were applied on May 22 in 2012 and on May 20 in 2013, respectively. All field experiments were conducted in sugarcane plots of 3 rows $(5.5 \mathrm{~m})$ wide by $15.2 \mathrm{~m}$ long each and replicated 4 times.

\subsection{Ammonia collection and analysis}

Ammonia was collected using an active chamber method with continuous flushing of the $\mathrm{NH}_{3}$-free pure outside air into the closed chamber systems installed in the experimental fields. It has been shown by various studies that active chamber methods are much more efficient on measuring $\mathrm{NH}_{3}$ emission as compared to the passive chambers (Marshall and Debell, 1980; Ruess and McNaughton, 1988; Frank and Zhang, 1997; Harper, 2005; Hou et al., 2007; Das et al., 2008). In addition, flushing or air circulation can also be used to collect enough $\mathrm{NH}_{3}$ volatilization in a very short period of time by creating sufficient air turbulence inside the 
chambers (Marshall and Debell, 1980; Harper, 2005). In this study, stainless steel top (0.3 x $0.3 \mathrm{x}$ $\left.0.26 \mathrm{~m}^{3}\right)$ and bottom chambers $\left(0.3 \times 0.3 \times 0.2 \mathrm{~m}^{3}\right)$ were used to collect $\mathrm{NH}_{3}$ emitted from the soil (Fig. 1). Inner walls of the chambers were coated with polytetrafluoroethylene (PTFE) sheets to prevent $\mathrm{NH}_{3}$ from reacting with the stainless steel because $\mathrm{NH}_{3}$ is very reactive and could react with measurement equipment (Roelle and Aneja, 2002; Das et al., 2008). The bottom chambers were placed $10 \mathrm{~cm}$ deep in the soil of the sugarcane rows and were kept undisturbed for the whole sampling season. During each sampling event, the top chambers were connected with the bottom chambers using clamps and the whole chamber system in the field was covered with reflective insulation sheets, which prevent the metal chamber from heating due to direct sun light. Ethylene propylene diene monomer (EPDM) rubber weather strips were placed on top of both the chambers for close sealing when clamped during sampling. The outside air was drawn in a dilute citric acid (4\%) trap through teflon tubing to eliminate the $\mathrm{NH}_{3}$ in the air before flowing into the closed chamber. The $\mathrm{NH}_{3}$-free air then flushed the chamber gas into the second citric acid trap for collecting volatilized $\mathrm{NH}_{3}$. The flushing and collection system was powered by an air sampling pump (LaMotte company, Maryland) and operated at a flow rate of 1.5 litres per minute (LPM) for 90 minutes. The flow rate and flushing time were chosen based on our preliminary experiment to ensure that flushing rate was greater than $\mathrm{NH}_{3}$ emission rate and at least 3 times of chamber volume was collected.

The first $\mathrm{NH}_{3}$ sample was taken 2 hours after fertilizer application followed by every alternate day for first three weeks and then once a week for two and half months in 2012 and for about 4 months in 2013. One $\mathrm{NH}_{3}$ sampling was missed from residue plot (at $11 \mathrm{DAN}$ ) due to some technical problems in 2013. All $\mathrm{NH}_{3}$ samples collected in dilute citric acid were analyzed using ion chromatography (Dionex, ICS-2000). Soil and air temperatures were taken by portable 
soil temperature probe with every $\mathrm{NH}_{3}$ sampling. Composite surface soil samples were also collected and analyzed for soil moisture content. Rainfall data were obtained for the experiment sites from the LSU AgCenter weather station website for St Gabriel research station.

\subsection{Emission factor (EF) analysis}

The emission factor $(\mathrm{EF})$ of $\mathrm{NH}_{3}-\mathrm{N}$ for the entire sugarcane growing season was analyzed using the following formula:

$$
\mathrm{EF}(\%)=\frac{\sum\left(\mathrm{NH}_{3}-\mathrm{N}\right)_{\text {fetilizer }}-\left(\mathrm{NH}_{3}-\mathrm{N}\right)_{\text {control }}}{\text { Applied available N source }} \times 100
$$

Where $\mathrm{NH}_{3}-\mathrm{N}_{\text {fertilizer }}$ and $\mathrm{NH}_{3}-\mathrm{N}_{\text {control }}$ are the total $\mathrm{NH}_{3}-\mathrm{N}$ emissions from the fertilized field and from the control plot, respectively. Applied available $\mathrm{N}$ source is the amount of $\mathrm{N}$ applied in the field $\left(\mathrm{kg} \mathrm{ha}^{-1}\right)$.

\subsection{Statistical analysis}

Statistical analyses were done using SAS 9.3 (SAS Institute. 2012, Cary, NC) for analysis of variance (ANOVA) with PROC MIXED and mean separation was done by Tukey-Kramer method at a $P<0.05$ level.

\section{RESULTS AND DISCUSSION}

\subsection{Soil and environmental parameters}

High soil and air temperatures occurred throughout the whole sampling season. Average soil and air temperature was very similar for both the years (Fig. 2 \& 4). Year 2013 received twice the number of rainfall days as compared to 2012. But half of the rainfall was received within 3 weeks of fertilization in 2012, whereas, $75 \%$ of the rainfall was received after 3 weeks 
of fertilizer application in 2013. Bulk density of the RR treatment plots was found to be $6.5 \%$ lower than the RB plots which indicated that residue retention improved soil structure by adding organic matter to the soil (Kornecki and Fouss, 2011; Blanco-Canqui et al., 2009). Average soil moisture content, as expressed as WFPS of RR plots, was 5-6\% higher as compared to that of RB plots in 2012 and 2013, respectively.

\subsection{Ammonia volatilization from 2012 field experiment}

Ammonia volatilization as impacted by different fertilizer applications and residue management treatments is presented in Fig 2. Ammonia samples were collected till 71 DAN from all field plots due to hurricane Isaac which caused significant lodging in 2012. Nonetheless, major portion of $\mathrm{NH}_{3}$ emission was captured before the hurricane occurred. Significant $\mathrm{NH}_{3}-\mathrm{N}$ loss began a day after fertilizers were applied with sharp emission peaks at 2 and 17 DAN, which corresponded to higher soil moisture levels after rainfall events (Fig. 2B) and higher soil and air temperatures (Fig. 2C). The majority of the volatilization losses were found within 3 weeks after $\mathrm{N}$ application. This was especially true for urea treated plots in both RB and RR management schemes, accounting for $67-69 \%$ of the total seasonal cumulative $\mathrm{NH}_{3}-\mathrm{N}$ losses from the field. After 3 weeks, the $\mathrm{NH}_{3}$ emission decreased significantly. Several studies also found significant loss of $\mathrm{NH}_{3}$ within the first 3 weeks following $\mathrm{N}$ fertilizer application for paddy rice and cereal crops (Hou et al., 2007; Turner et al., 2012; Ruijter et al., 2010). On the other hand, the general decline in $\mathrm{NH}_{3}$ emission with time could be due to lower availability of ammonia caused by nitrification and $\mathrm{NH}_{4}{ }^{+}$fixation in clay lattices as well as by decreased soil pH (Black et al., 1985; Sommer and Jensen, 1994). 
Different $\mathrm{N}$ sources had considerable impacts in $\mathrm{NH}_{3}$ emission from the sugarcane field. Urea-treated plots showed significantly higher $\mathrm{NH}_{3}-\mathrm{N}$ emission $(P<0.05)$ than UAN and the control irrespective of the residue management treatments within the first 30 days of $\mathrm{N}$ application (Fig.2A). As cumulatively for the season, urea plots produced about an average of 2.1 times higher $\mathrm{NH}_{3}-\mathrm{N}$ emissions than UAN plots over the sample collection period $(8.1 \mathrm{~kg} \mathrm{~N}$ ha $^{-1}$ season $^{-1}$ vs. $3.8 \mathrm{~kg} \mathrm{~N} \mathrm{ha}^{-1}$ season $^{-1}$ ) (Fig. 3). Other studies also reported 1.5-2.4 times higher emissions from urea application than from UAN fertilization for pasture wheat and barley (Vaio et al., 2007; Turner et al. 2012). The UAN plots had generally higher cumulative $\mathrm{NH}_{3}$ emissions than the control plots but the difference was not statistically significant, indicating the relative advantage of using $\mathrm{UAN}$ to minimize $\mathrm{NH}_{3}$ volatilization by $\mathrm{N}$ fertilizer application in sugarcane production.

Significant effects of residue management schemes on $\mathrm{NH}_{3}-\mathrm{N}$ emission were also seen from daily observations (Fig. 2A). The RR treatments had an average daily emission of $16.2 \mathrm{~g}$ $\mathrm{NH}_{3}-\mathrm{N}_{\text {ha }}{ }^{-1}$ day $^{-1}$, which was significantly $(P<0.05)$ higher than the average daily $\mathrm{NH}_{3}$ loss of 10.6 $\mathrm{g} \mathrm{N} \mathrm{ha}^{-1} \mathrm{day}^{-1}$ from RB plots over the season. This difference was particularly significant when urea was applied (Fig. 3). This was likely due to the generally higher soil water moisture under the RR management scheme (Mulumba and Lal, 2008), which facilitates the urease to hydrolyze urea into $\mathrm{NH}_{3}-\mathrm{N}$. Leaving crop residues as a blanket on the soil has been found to increase $\mathrm{NH}_{3}$ volatilization significantly compared to the residues incorporated in the soil (Manheim et al., 1997; Ruijter et al., 2010). On the other hand, soils with retained stubbles were showed to have generally higher $\mathrm{C} / \mathrm{N}$ ratios, which could help soil microorganisms such as ammonifiers to produce more $\mathrm{NH}_{3}$ through the decomposition of organic matter (Riedo et al., 
2002; Ruijter et al., 2010). Nonetheless, in this study, we did not find any statistically significant interactive effects of residue management and fertilizer source on gaseous $\mathrm{NH}_{3}$ losses.

\subsection{Ammonia volatilization from 2013 field experiment}

Ammonia fluxes from fertilizer source and residue management schemes were examined separately in 2013 to assess the impact of individual treatments. Gas flux samples were collected till 112 DAN (Fig. 4). Similar to 2012, significant $\mathrm{NH}_{3}-\mathrm{N}$ losses began one day after fertilizer application regardless of the experiments for fertilizer source or residue management scheme evaluations (Figs. 4A and 4B). As for the experiment comparing fertilizer sources within the RB treatment, the most commonly employed residue management practice in the Louisiana, average $\mathrm{NH}_{3}-\mathrm{N}$ emission from urea plots was $14.8 \mathrm{~g} \mathrm{~N} \mathrm{ha}^{-1}$ day $^{-1}$ or $5.7 \mathrm{~kg} \mathrm{~N}^{-1}$ season ${ }^{-1}$ which was significantly $(\alpha=0.05)$ higher than 12.2 and $7.0 \mathrm{~g} \mathrm{~N} \mathrm{ha}^{-1}$ day $^{-1}$ or 4.4 and $2.2 \mathrm{~kg} \mathrm{~N} \mathrm{ha}^{-1}$ season $^{-1}$, respectively, for both the UAN plots and the control (Fig. 5A). This result, unlike that of 2012 in the combined fertilizer source and residue management treatment experiment which showed only the significant difference in the RR residue management practice, further confirms the difference between urea and UAN applications in affecting $\mathrm{NH}_{3}-\mathrm{N}$ loss. Nonetheless, major portion of the volatilization losses (55\% of the total loss) was within 4 weeks after $\mathrm{N}$ application.

As for the experiment comparing two residue management schemes, the RR practice generally had higher $\mathrm{NH}_{3}-\mathrm{N}$ daily loss than the $\mathrm{RB}$ treatment during the whole sampling season (Fig. 4). Cumulatively, $\mathrm{NH}_{3}-\mathrm{N}$ emission from the RR plots was significantly higher with $26 \%$ greater than that from the RB plots for the season (Fig. 5B). Approximately 70-75\% of the total volatilization loss was observed within 42 days after $\mathrm{N}$ application. The latter was slightly longer 
than that observed in the year 2012, which generally showed the major emissions within the first 30 days of $\mathrm{N}$ fertilization. Relatively low soil temperature could be the cause for these slightly prolonged $\mathrm{NH}_{3}-\mathrm{N}$ emissions in 2013 , which seems to be more associated with the RR plots.

\subsection{Emission factors}

The average seasonal $\mathrm{NH}_{3}-\mathrm{N}$ EF, which considers only the emission from applied $\mathrm{N}$ after eliminating background process observed from the control plots, for different fertilizer applications under different residue management schemes are presented in Table 2. The EF values of urea application were clearly much greater than the UAN application. This was especially true under $\mathrm{RR}$ residue management scheme in which $\mathrm{NH}_{3}-\mathrm{N}$ EF from urea was approximately 3.3 folds of that from UAN as compared to 2.0 times under the RB management practice. This result suggests that granular urea application in sugarcane production systems generally has more than doubled $\mathrm{NH}_{3}-\mathrm{N}$ loss even though urea was immediately covered by soil after application through disking. The liquid nature of UAN through knifing in the soil clearly has the advantage of low volatility loss as $\mathrm{NH}_{3}$ emissions. On the other hand, the $\mathrm{RR}$ residue management had generally higher $\mathrm{NH}_{3}-\mathrm{N}$ EF than the RB residue management practice $(1.7 \%$ vs. $1.2 \%$ for UAN and $5.6 \%$ vs. $2.4 \%$ for urea), a result that is consistent with greater moisture as observed in the residue retained plots (Figs. 2A and 4C), which helps the hydrolysis of urea and facilitates $\mathrm{NH}_{3}$ emission loss (Manheim et al., 1997; Ruijter et al., 2010).

It should be pointed out that the previous research reported that keeping the residue blanket on soil surface reduced subsequent yield of sugarcane crops as compared to the residue burned treatment and one of main reasons for this decrease was often attributed to unfavorable negative soil water-temperature relations due to relatively cold winter as well as production of 
allelochemicals and overwintering sugarcane borers and sugarcane beetle (Richard, 2001; Kennedy and Arceneaux, 2006; Viator et al., 2008, 2009a). However, our study indicates that the greater loss of nutrient $\mathrm{N}$ as $\mathrm{NH}_{3}$ emission, facilitated by the residue blanket could be also a potentially contributing factor to this decreased yield phenomenon. In addition, toxicity of ammonia to plants has been reported at concentrations higher than $600 \mu \mathrm{g} \mathrm{NH}_{3} \cdot \mathrm{m}^{-3}$ for $24 \mathrm{~h}$ and $10,000 \mu \mathrm{g} \mathrm{mg} \mathrm{NH} \cdot \mathrm{m}^{-3}$ for $1 \mathrm{~h}$ (Van Der Eerden, 1982). While we did not measure the open air $\mathrm{NH}_{3}$ concentration, relatively high intensity of $\mathrm{NH}_{3}-\mathrm{N}$ emissions observed immediately following the fertilizer application in this study with urea under the residue retained management practice suggests it is not unlikely that $\mathrm{NH}_{3}$ concentration could reach the toxic level under the microclimate environment and cause the reduction of plant growth. This could be another factor contributing to the loss of sugarcane yield of subsequent sugarcane, which has not been adequately investigated.

The $\mathrm{NH}_{3}-\mathrm{N}$ EF values (2.4-5.6\%) reported in this study were higher than the $1.9 \%$ observed by Tian et al. (2015) in a granular urea-treated cotton field in the same region, suggesting sugarcane production tend to facilitate $\mathrm{NH}_{3}$ loss even though the soil used in this study has a pH 6.1 which is similar to $\mathrm{pH} 6.2$ of the soil in the cotton study. On the other hand, these EFs are much lower than the $17-39 \% \mathrm{NH}_{3}-\mathrm{N}$ loss of applied urea-N directly applied on trash (residue) covered sugarcane fields as observed in Queensland, Australia (Freney et al, 1992), suggesting that the soil incorporation of urea as practiced in Louisiana sugarcane production can dramatically reduce $\mathrm{NH}_{3}$ volatilization. These observed EFs are also much lower than the $23 \%$ of applied $N$ reported for pasture soils (Van Der Weerden and Jarvis, 1997) and $13.7 \%$ of average estimate of the loss for urea applications from many other upland crop 
production studies (Yan et al., 2003). These results clearly demonstrate the effects of crop systems and associated field management practices on $\mathrm{NH}_{3}-\mathrm{N}$ emissions.

\subsection{Relationship between $\mathrm{NH}_{3}$ emissions and soil WFPS}

Higher peaks of $\mathrm{NH}_{3}$ emissions were generally observed immediately after high rainfall events such as days 2, 17 and 34 in 2012 and days 2 and 12 in 2013 especially when N fertilizers were just applied. Previous research has showed that rainfall and resulting soil water dynamics highly influences the hydrolysis of urea and eventually $\mathrm{NH}_{3}$ volatilization particularly as soil begins to dry due to an increase in diffusion (Corre et al., 2002; Arnibar et al., 2004; Tian et al., 2015). In this study, while we did not find direct statistically significant correlation between rainfall amount and $\mathrm{NH}_{3}-\mathrm{N}$ emission over a sampling season, there was significant correlation between the soil moisture content as expressed by WFPS (\%) and the magnitude of daily $\mathrm{NH}_{3}-\mathrm{N}$ emission for each season (Fig 6). Average WFPS in 2013 was about 25\% higher than 2012 because of more frequent rainfall events and greater overall total amounts of precipitation received during the sampling period in 2013. However, the results showed that the average WFPS had much higher correlation with average $\mathrm{NH}_{3}$ emission of combined $\mathrm{N}$ fertilizers in 2012 $\left(R^{2}=0.61, P<0.01\right)$ than $2013\left(R^{2}=0.27, P<0.05\right)$. Most rainfall events in 2013 occurred 3 weeks after fertilization, when $\mathrm{NH}_{3}$ emissions were already very low. Whereas, in 2012, more than half of the rainfall events were within 3 weeks of fertilization, when, the $\mathrm{NH}_{3}$ emissions were relatively higher than rest of the sampling period. Separately, WFPS showed slightly greater correlation with $\mathrm{NH}_{3}-\mathrm{N}$ emission from urea $\left(R^{2}=0.48\right)$ than from $\mathrm{UAN}\left(R^{2}=0.32\right)$ for 
both the years. Also, it was found that the plots with RR treatments had generally higher correlations with WFPS $\left(R^{2}=0.67\right.$ in 2012 and 0.29 in 2013) than RB plots $\left(R^{2}=0.47\right.$ in 2012 and 0.21 in 2013) because the residue blanket in the field retained more soil moisture and thus subsequently increased the WFPS $(\%)$. Previous studies of different $\mathrm{N}$ fertilizer sources have showed that WFPS did not significantly influence $\mathrm{NH}_{3}$ emissions from soil or that higher emissions were only found in a WFPS range primarily between 8-30\% (Fenn and Escarzaga, 1976; Bouwmeester et al., 1985; Akiyama et al., 2004). Our study appears to indicate that $\mathrm{NH}_{3^{-}}$ $\mathrm{N}$ emissions in $\mathrm{N}$ fertilizer-treated sugarcane fields generally increased with increasing WFPS up to $45-55 \%$ observed in the field.

Overall, we did not observe any statistically significant relationship between soil and air temperatures with $\mathrm{NH}_{3}$ volatilization, even though some higher $\mathrm{NH}_{3}$ emissions corresponded to high soil and air temperatures on certain days.

\section{CONCLUSIONS}

Two years of field experiments clearly showed that $\mathrm{N}$ fertilizer source had a significant impact on $\mathrm{NH}_{3}$ emissions from soil under sugarcane production. Urea application produced significantly higher $\mathrm{NH}_{3}$ volatilization with emission factor of twice or more than the application of UAN depending on the harvest residue management of proceeding crops. The residue retention management approach showed generally higher average $\mathrm{NH}_{3}$ emission than that of the ground burning of harvested residue following $\mathrm{N}$ fertilizer application, due to higher soil moisture retained by the former, which helped hydrolysis of urea and subsequently $\mathrm{NH}_{3}$ emissions. The significantly highest amount of $\mathrm{NH}_{3}$ volatilization was measured within 4 weeks after $\mathrm{N}$ application and it was generally increased with increasing WFPS up to 45-55\%. This 
study demonstrates the importance of both fertilization applications and harvest crop residue management approaches in affecting $\mathrm{NH}_{3}$ emission factors from sugarcane production.

\section{ACKNOWLEDGEMENT}

This work was supported in part by the USDA-NIFA-AFRI Grant Award No. 201085112-20509. Contribution of Louisiana Agric. Exp. Stn. Journal No. _ and is published with the approval of the Director.

\section{REFERENCES}

Akiyama, H., McTaggart, I.P., Ball, B.C., Scott, A., 2004. $\mathrm{N}_{2} \mathrm{O}$, NO, and $\mathrm{NH}_{3}$ emissions from soil after the application of organic fertilizers, urea and water. Water Air Soil Poll. 156, 113-129.

Anderson, N., Strader, R., Davidson, C., 2003. Airborne reduced nitrogen: ammonia emissions from agriculture and other sources. Environ. Int. 29, 277-286.

Aranibar, J.N., Otter, L., Macko, S.A., Feral, C.J.W., Epstein, H.E., Dowty, P.R., Eckardt, F., Shugart, H.H., Swap, R.J., 2004. Nitrogen cycling in the soil-plant system along a precipitation gradient in the Kalahari sands. Glob. Change Biol. 10, 359-373.

Bauer, S.E., Koch, D., Unger, N., Metzger, S.M., Shindell, D.T., Streets, D.G., 2007. Nitrate aerosols today and in 2030: a global simulation including aerosols and tropospheric ozone. Atmos. Chem. Phys. 7, 5043-5059.

Behera, S.N., Sharma, M., Aneja, V.P., Balasubramanian, R., 2013. Ammonia in the atmosphere: a review on emission sources, atmospheric chemistry and deposition on terrestrial bodies. Environ. Sci. Poll. R. 20, 8092-8131.

Behera, S.N., Betha, R., Balasubramanian, R., 2013. Insights into chemical coupling among acidic gases, ammonia and secondary inorganic aerosols. Aerosol Air Qual. Res. 13, 1282-1296.

Black A.S., Sherlock R.R., Cameron K.C., Smith N.P., Goh, K.M., 1985. Comparison of three field methods for measuring ammonia volatilization from urea granules broadcast on to pasture. J. Soil Sci. 36, 271-280.

Blanco-Canqui, H., Stephenson, R.J., Nelson, N.O., Presley, D.R., 2009. Wheat and sorghum residue removal for expanded uses increases sediment and nutrient loss in runoff. J. Environ. Qual. 38, 2365-2372. 
Bosch-Serra, A.D., Yague, M.R., Teira-Esmatges, M.R., 2014. Ammonia emissions from different fertilizing strategies in Mediterranean rainfed winter cereals. Atmos. Environ. 84, 204-212.

Bouwmeester, R.J.B., Viek, P.L.G. Stumpe, J.M., 1985. Effect of environmental factors on ammonia volatilization from urea-fertilized soil. Soil Sci. Soc. Am. J. 49, 376-381.

Bouwman, A.F., Lee, D.S., Asman, W.A.H., Dentener, F.J., Van Der Hoek, K.W., Olivier, J.G.J., 1997. A global high-resolution emission inventory for ammonia. Global Biogeochem. Cy. 11, 561-587.

Corre, M.D., Schnabel, R.R., Stout, W.L., 2002. Spatial and seasonal variation of gross nitrogen transformations and microbial biomass in a Northeastern US grassland. Soil Biol. Biochem. 34, 445-457.

Das, P., Kim, K.H., Sa, J.H., Bae, W.S., Kim, J.C., Jeon, E.C., 2008. Emissions of ammonia and nitric oxide from an agricultural site following application of different synthetic fertilizers and manures. Geosci. J. 12, 177-190.

Fageria, N.K., Baligar, V.C., Jones, C.A., 1997. Growth and Mineral Nutrition of Field Crops. $2^{\text {nd }}$ edition, New York: Marcel Dekker. pp. 476.

Fenn, L.B., Escarzaga, R., 1976. Ammonia volatilization from surface applications of ammonium compounds on calcareous soils: V. Soil water content and method of nitrogen application. Soil Sci. Soc. Am. J. 40, 537-541.

França, D.D.A., Longo, K.M., Neto, T.G.S., Santos, J.C., Freitas, S.R., Rudorff, B.F., Ely V.C, Edson A., Carvalho, J.A., 2012. Pre-harvest sugarcane burning: determination of emission factors through laboratory measurements. Atmosphere, 3, 164-180.

Frank D.A., Zhang Y. 1997. Ammonia volatilization from seasonally and spatially variable grazed grassland: Yellowstone National Park. Biogeochem. 36, 189-203.

Freney, J.R., Denmead, O.T., Wood, A.W., Saffigna, P.G., Chapman, L.S., Ham, G.J., Hurney, A.P., Stewart, R.L., 1992. Factors controlling ammonia loss from trash covered sugarcane fields fertilized with urea. Fertilizer Res. 31, 341-349.

Goebes, M.D., Strader, R., Davidson, C., 2003. An ammonia emission inventory for fertilizer application in the United States. Atmos. Environ. 37, 2539-2550.

Gong, W., Zhang, Y., Huang, X., Luan, S., 2013. High-resolution measurement of ammonia emissions from fertilization of vegetable and rice crops in the Pearl River delta region, China. Atmos. Environ. 65, 1-10. 
Harper, L.A., 2005. Ammonia: Measurement Issues. J.L. Hatfield, J.M. Baker (Eds.), Micrometeorological Measurements in Agricultural Systems, ASA, CSSA, and SSSA, Madison, WI. pp. 345-379.

Hou, H., Zhou, S., Hosomi, M., Toyota, K., Yosimura, K., Mutou, Y., Nisimura, T., Takayanagi. M., Motobayashi, T., 2007. Ammonia emissions from anaerobically-digested slurry and chemical fertilizer applied to flooded forage rice. Water Air Soil Poll. 183, 37-48.

Hutchings, N.J., Sommer, S.G., Andersen, J.M., Asman, W.A., 2001. A detailed ammonia emission inventory for Denmark. Atmos. Environ. 35, 1959-1968.

Hyde, B.P., Carton, O.T., O’toole, P., Misselbrook, T.H., 2003. A new inventory of ammonia emissions from Irish agriculture. Atmos. Environ. 37, 55-62.

Kennedy, C.W., Arceneaux. A.E., 2006. The effect of harvest residue management inputs on soil respiration and crop productivity of sugarcane. J. Am. Soc. Sugarcane Technol. 26, 125136.

Kornecki, T.S., Fouss, J.L., 2011. Sugarcane residue management effects in reducing soil erosion from quarter drains in Southern Louisiana. Appl. Eng. Agric. 27, 597-603.

Mannheim, T., Braschkat, J., Marschner, H., 1997. Ammonia emissions from senescing plants and during decomposition of crop residues. J. Plant Nutri. Soil Sci. 160, 125-132.

Marshall, V.G., Debell, D.S., 1980. Comparison of four methods of measuring volatilization losses of nitrogen following urea fertilization of forest soils. Can. J. Soil Sci. 60, 549-563.

Mulumba, L.N., Lal, R., 2008. Mulching effects on selected soil physical properties. Soil Till. Res. 98, 06-111.

Myhre, G., Berglen, T.F., Johnsrud, M., Hoyle, C.R., Berntsen, T.K., Christopher, S.A., Fahey, D.W., Isaksen, I.S.A., Jones, T.A., Kahn, R.A., Loeb, N., Quinn, P., Remer, L., Schwarz, J.P., Yttri, K.E., 2009. Modelled radiative forcing of the direct aerosol effect with multiobservation evaluation. Atmos. Chem. Phys. 9, 1365-1392.

Pain, B.F., Van der Weerden, T.J., Chambers, B.J., Phillips, V.R., Jarvis, S.C., 1998. A new inventory for ammonia emissions from UK agriculture. Atmos. Environ. 32, 309-313.

Richard, E.P., Jr. 2001. Management of chopper harvester-generated green cane trash blankets: a new concern for Louisiana. Proc. Int. Soc. Sugar Cane Technol. 23, 52-62.

Riedo, M., Milford, C., Schmid, M., Sutton, M.A., 2002. Coupling soil-plant-atmosphere exchange of ammonia with ecosystem functioning in grasslands. Ecol. Model. 158, 83110. 
Roelle, P.A., Aneja, V.P., 2002. Characterization of ammonia emissions from soils in the upper coastal plain, North Carolina. Atmos. Environ. 36, 1087-1097.

Ruess, R.W., McNaughton, S.J., 1988. Ammonia volatilization and the effects of large grazing mammals on nutrient loss from East African grasslands. Oecologia. 77, 382-386

Ruijter, F.J., Huijsmans, J.F.M., Rutgers, B., 2010. Ammonia volatilization from crop residues and frozen green manure crops. Atmos. Environ. 44, 3362-3368.

Seinfeld, J.H., Pandis, S.N., 1998. Atmospheric Chemistry and Physics: from air pollution to climate change. New York, NY. John Wiley \& Sons. Pp. 1077-1099.

Sommer, S.G., Jansen, C., 1994. Ammonia volatilization from urea and ammoniacal fertilizers surface applied to winter wheat and grassland. Fertilizer Res. 37, 85-92.

Southwick, L.M., Grigg, B.C., Kornecki, T.S., Fouss, J.L., 2001. Potential influence of sugarcane cultivation on estuarine water quality of Louisiana's Gulf Coast. J. Agr. and Food Chem. 50, 4393-4399.

Stephen, K., Aneja, V.P., 2008. Trends in agricultural ammonia emissions and ammonium concentrations in precipitation over the Southeast and Midwest United States. Atmos. Environ. 42, 3238-3252.

Tian, Z., Wang, J.J., Liu, S., Zhang, Z., Dodla, S.K., Myers, G., 2015. Application effects of coated urea and urease and nitrification inhibitors on ammonia and greenhouse gas emissions from a subtropical cotton field of the Mississippi delta region. Sci. Total Environ. 533, 329-338.

Turner, D.A., Edis, R.E., Chen, D., Freney, J.R., Denmead, O.T., 2012. Ammonia volatilization from nitrogen fertilizers applied to cereals in two cropping areas of Southern Australia. Nutr. Cycl. Agroecosyst. 93, 113-126.

Udeigwe, T.K., J.J. Wang, H.P. Viator, L. Gaston., 2010. Surface Water Quality as Affected by Sugarcane Residue Management Techniques. Water Air Soil Poll. 208, 119-128.

USEPA 2014. The particle pollution report: current understanding of air quality and emissions through 2003. USEPA \# 454-R-04-002. US Environmental Protection Agency, office of Air Quality Planning and Standards. Research Triangle Park, NC, 27709. Available from: http://www.epa.gov/airtrends/aqtrnd04/pmreport03/pmunderstand_2405.pdf.

USEPA 2015. Inventory of U.S. greenhouse gas emissions and sinks. USEPA \# 430-R-15-004. 1200 Pennsylvania Ave. N.W., Washington D.C., USA. Available from: http://www3.epa.gov/climatechange/Downloads/ghgemissions/US-GHG-Inventory-2015Chapter-5-Agriculture.pdf

Vaio, N., Cabrera, M.L., Kissel, D.E., Rema, J.A., Newsome, J.F., Calvert, II. V.H., 2008. Ammonia volatilization from urea-based fertilizers applied to tall fescue pastures in Georgia, USA. Soil Sci. Soc. Am. J. 72, 1665-1671. 
Van Der Eerden, L.J.M., 1982. Toxicity of ammonia to plants. Agr. Environ. 7, 223-235.

Van der Weerden, Jarvis, S.C., 1997. Ammonia emission factors for $\mathrm{N}$ fertilizers applied to two contrasting grassland soils. Environ. Poll. 95, 205-211.

Viator, R.P., Johnson, R.M., Richard, E.P., Waguespack, H.L., Jackson, W., 2008. Influence of nonoptimal ripener applications and postharvest residue retention on sugarcane second ratoon yields. Agron. J. 100, 1769-1773.

Viator, H. P., Flanagan, J., Gaston, L., Hall, S., Hoy, J., Hymell, T., Kennedy, C., Legendre, B., Wang, J.J., Zhou, M., 2009a. The influence of post-harvest residue management on water quality and sugarcane yield in Louisiana. J. American Soc. Sugarcane Technol. 29, 1-10.

Viator, R.P., 2009b. Effects of mechanical removal and incorporation of post-harvest residue on ratoon sugarcane yields. Sugarcane Int. 27, 149-152.

West, J.J., Ansari, A.S., Pandis, S.N., 1999. Marginal PM25: nonlinear aerosol mass response to sulfate reductions in the Eastern United States. J. Air Waste Manage. Assoc. 49, 14151424.

Wood, A.W. 1991. Management of crop residues following green harvesting of sugarcane in north Queenslan,d. Soil Till. Res. 20, 69-85.

Wu, S-Y., Krishnan, S., Zhang, Y. Aneja, V., 2008. Modeling atmospheric transport and fate of ammonia in North Carolina Part I: Evaluation of meteorological and chemical predictions. Atmos. Environ. 42, 3419-3436.

Yan, X., Akimoto, H., Ohara T., 2003. Estimation of nitrous oxide, nitric oxide and ammonia emissions from croplands in East, Southeast and South Asia. Glob. Change Biol. 9, 10801096.

Yang, Y., Zhou, C., Li, N., Han, K., Meng, Y., Tian, X., Wang, L., 2015. Effects of conservational tillage practices on ammonia emissions from loess plateau rain-fed winter wheat fields. Atmos. Environ. 104, 59-68

Zhang, Y., Liu, J., Mu, Y., Pei, S., Lun, X., and Chai, F., 2011. Emissions of nitrous oxide, nitrogen oxides and ammonia from a maize field in the North China plain. Atmos. Environ. 45, 2956-2961. 


\section{Figure captions}

Fig 1. Schematic diagram of an active chamber system used for ammonia collection.

Fig 2. 2012 field observations following $\mathrm{N}$ applications: (A) daily $\mathrm{NH}_{3}-\mathrm{N}$ losses, (B) rainfall and water filled pore space, and (C) air and soil temperatures.

Fig 3. Accumulated seasonal $\mathrm{NH}_{3}-\mathrm{N}$ losses from the sugarcane field under different residue and fertilizer treatments in 2012. The same lowercase letters on top of the bar diagram represents statistically insignificant at $\alpha=0.05$ level.

Fig 4. 2013 field observations following N applications: (A) daily NH3-N losses, (B) rainfall and water filled pore space, and $(\mathrm{C})$ air and soil temperatures.

Fig 5. Accumulated seasonal $\mathrm{NH}_{3}-\mathrm{N}$ losses in 2013 from the sugarcane field under (A) different fertilizer treatments and (B) residue managements. The same lowercase letters on top of the bar diagram represents statistically insignificant at $\alpha=0.01$ or 0.05 level.

Fig 6. Relation between daily ammonia losses and water filled pore space (\%) in 2012 and 2013. 
Table 1: Selected soil physical and chemical properties of the experimental field

\begin{tabular}{ll}
\hline Parameters & Avg. values \\
\hline $\mathrm{pH}(1: 1)$ & $6.1 \pm 0.5$ \\
${ }^{\S} \mathrm{CEC}(\mathrm{meq} / 100 \mathrm{gm})$ & $15.1 \pm 2.9$ \\
${ }^{\text {II }} \mathrm{Sand}(\%)$ & 22 \\
${ }^{\mathrm{I}} \mathrm{Silt}(\%)$ & 62 \\
${ }^{\Phi} \mathrm{Clay}(\%)$ & 16 \\
${ }^{\ddagger} \mathrm{C}(\%)$ & $0.9134 \pm 0.087$ \\
${ }^{\dagger} \mathrm{N}(\%)$ & $0.0878 \pm 0.923$ \\
${ }^{\Psi} \mathrm{P}\left(\mathrm{mg} \mathrm{kg}^{-1}\right)$ & $28.7 \pm 4.8$ \\
${ }^{\Psi} \mathrm{K}\left(\mathrm{mg} \mathrm{kg}^{-1}\right)$ & $105.1 \pm 15.5$ \\
${ }^{\Psi} \mathrm{Ca}\left(\mathrm{mg} \mathrm{kg}^{-1}\right)$ & $2006.2 \pm 252$ \\
${ }^{\Psi} \mathrm{Mg}\left(\mathrm{mg} \mathrm{kg}^{-1}\right)$ & $415.3 \pm 41.8$ \\
${ }^{\Psi} \mathrm{S}\left(\mathrm{mg} \mathrm{kg}^{-1}\right)$ & $44.9 \pm 6.8$ \\
\hline
\end{tabular}

${ }^{\S}$ Cation exchange capacity (CEC) was analyzed using ammonium acetate replacement method "Particle size distribution (sand, silt and clay) was done using pipette method ${ }^{\ddagger}$ Carbon and $\mathrm{N}$ was analyzed in Carbon-nitrogen analyzer

${ }^{\Psi}$ Elemental analysis was done using Mehlich-3 extraction followed by ICP analysis 
Table 2: Average emission factor $(\mathrm{EF})$ of $\mathrm{NH}_{3}-\mathrm{N}$ of different $\mathrm{N}$ treatments from sugarcane field

\begin{tabular}{lll}
\hline \multirow{2}{*}{ Treatment } & \multicolumn{2}{c}{ Emission factor $(\%)$} \\
\cline { 2 - 3 } & Residue burned & Residue retained \\
\hline Control & -- & -- \\
UAN & $1.2 \pm 0.15$ & $1.7 \pm 0.26$ \\
Urea & $2.4 \pm 0.32$ & $5.6 \pm 0.82$ \\
\hline
\end{tabular}




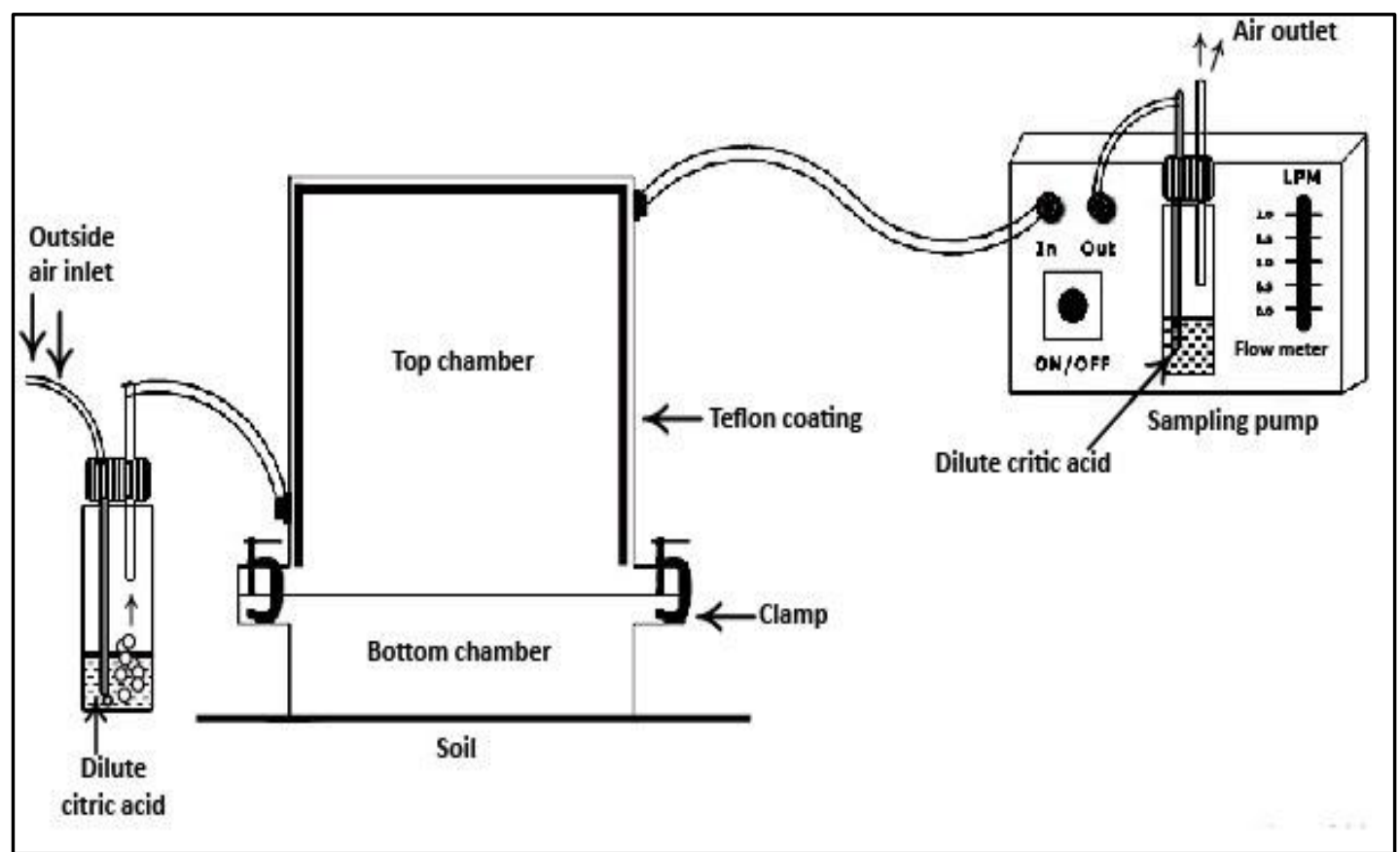

Fig 1. Schematic diagram of an active chamber system used for ammonia collection 

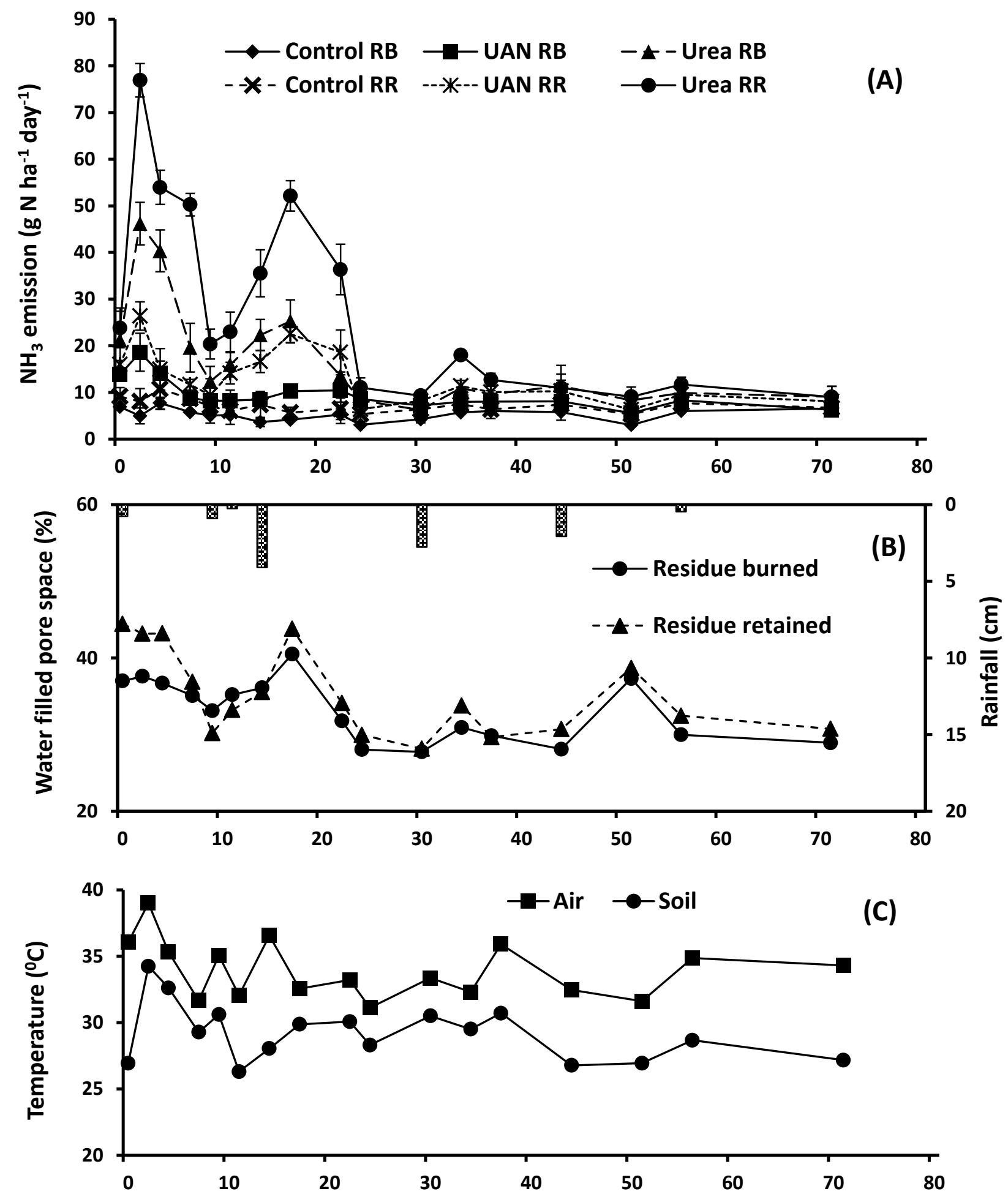

Days after $\mathbf{N}$ application

Fig 2. 2012 field observations following $\mathrm{N}$ applications: (A) daily $\mathrm{NH}_{3}-\mathrm{N}$ losses, (B) rainfall and water filled pore space, and (C) air and soil temperatures. 


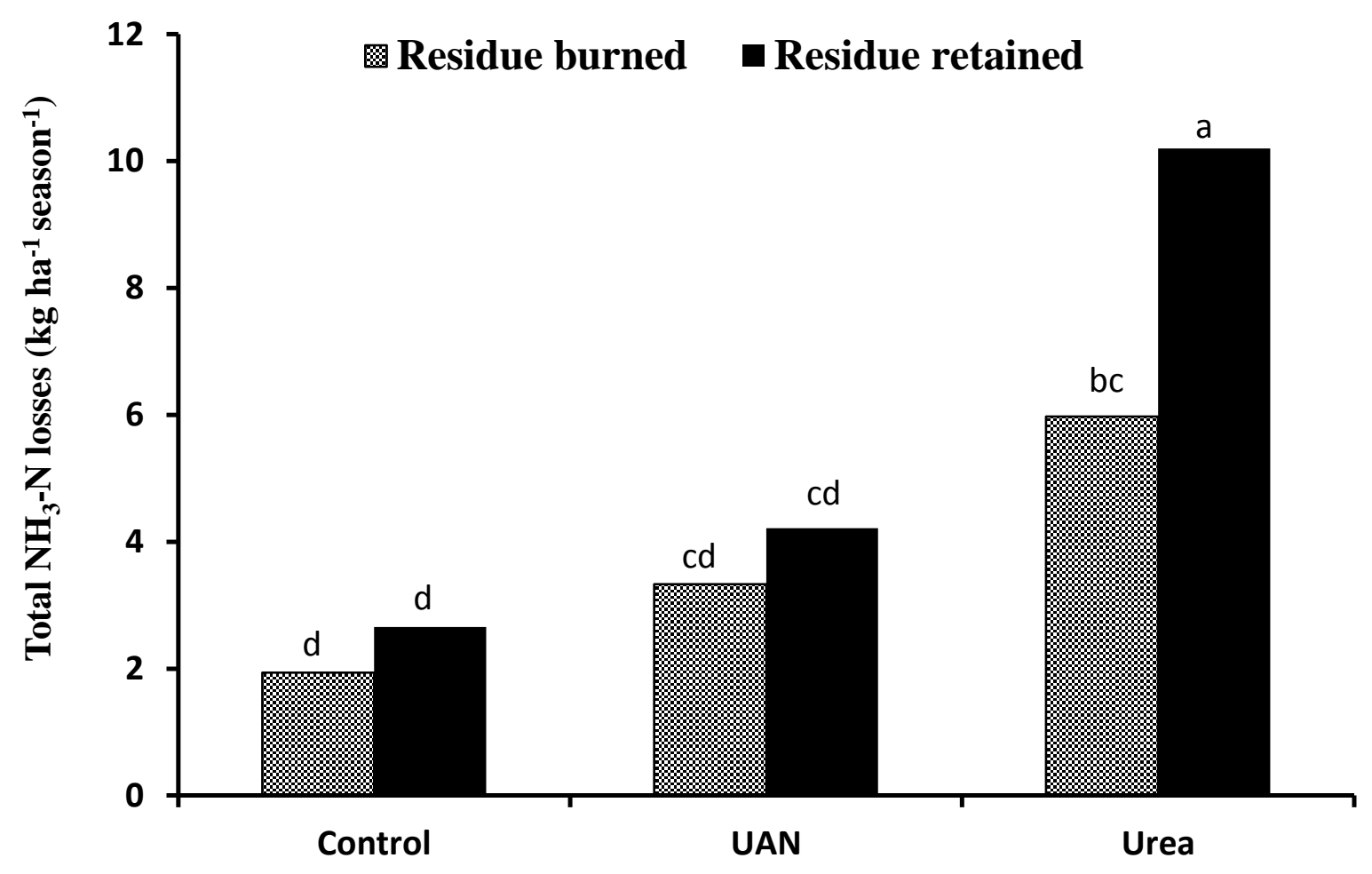

Fig 3. Accumulated seasonal $\mathrm{NH}_{3}-\mathrm{N}$ losses from the sugarcane field under different residue and fertilizer treatments in 2012. The same lowercase letters on top of the bar diagram represents statistically insignificant at $\alpha=0.05$ level. 

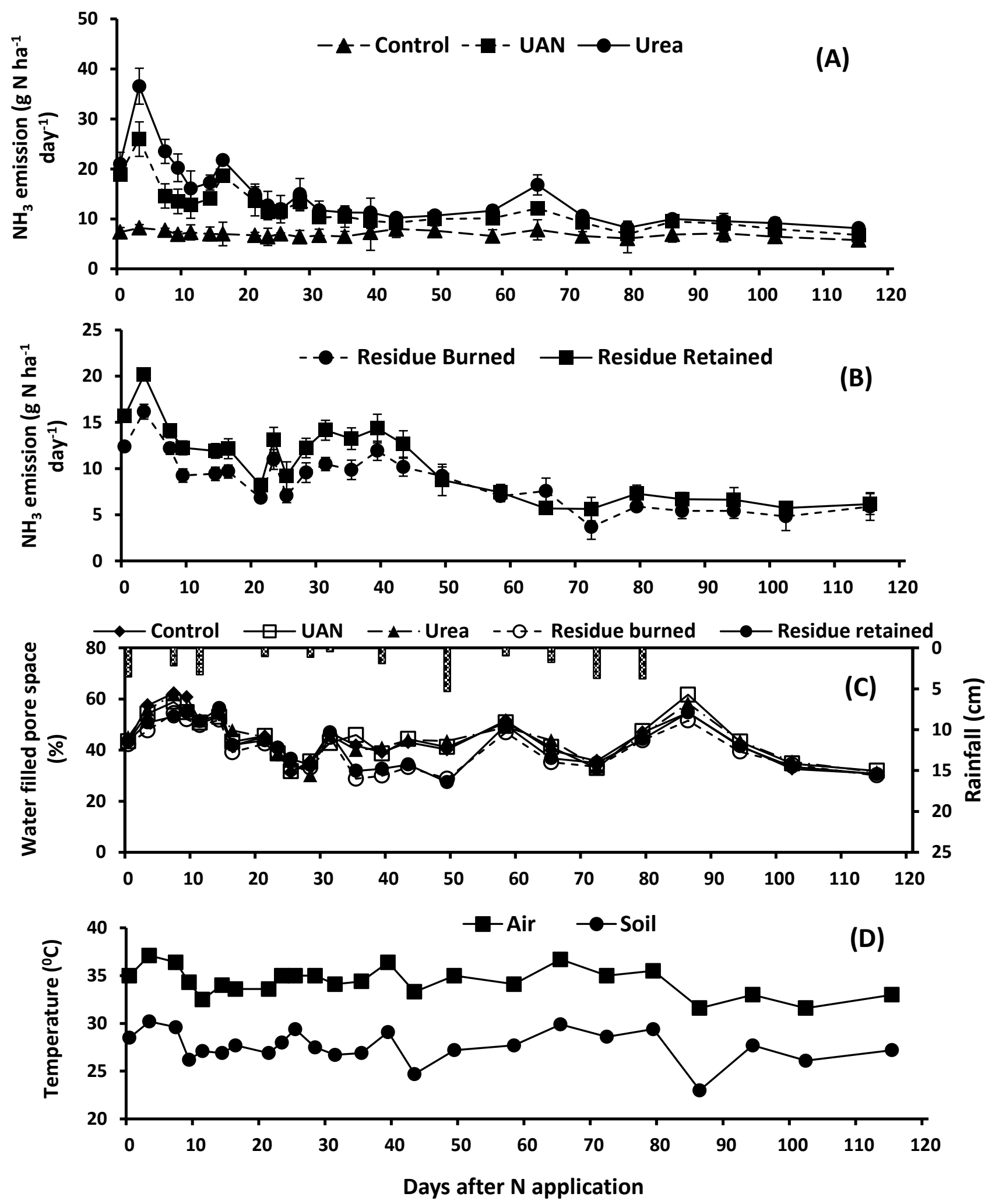

Fig 4. 2013 field observations following N applications: (A) daily NH3-N losses, (B) rainfall and water filled pore space, and $(\mathrm{C})$ air and soil temperatures. 

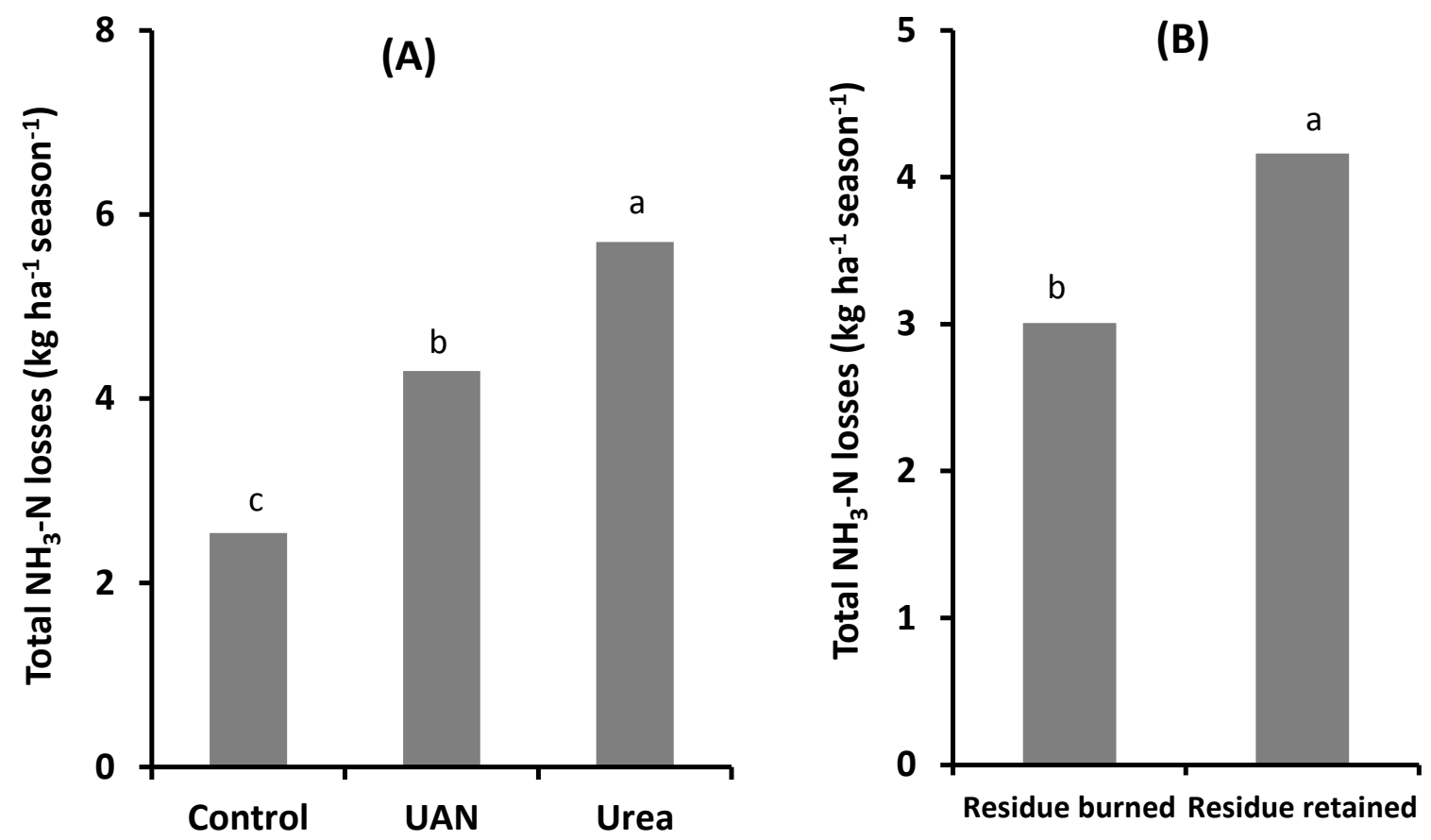

Fig 5. Accumulated seasonal $\mathrm{NH}_{3}-\mathrm{N}$ losses in 2013 from the sugarcane field under (A) different fertilizer treatments and (B) residue managements. The same lowercase letters on top of the bar diagram represents statistically insignificant at $\alpha=0.01$ or 0.05 level. 


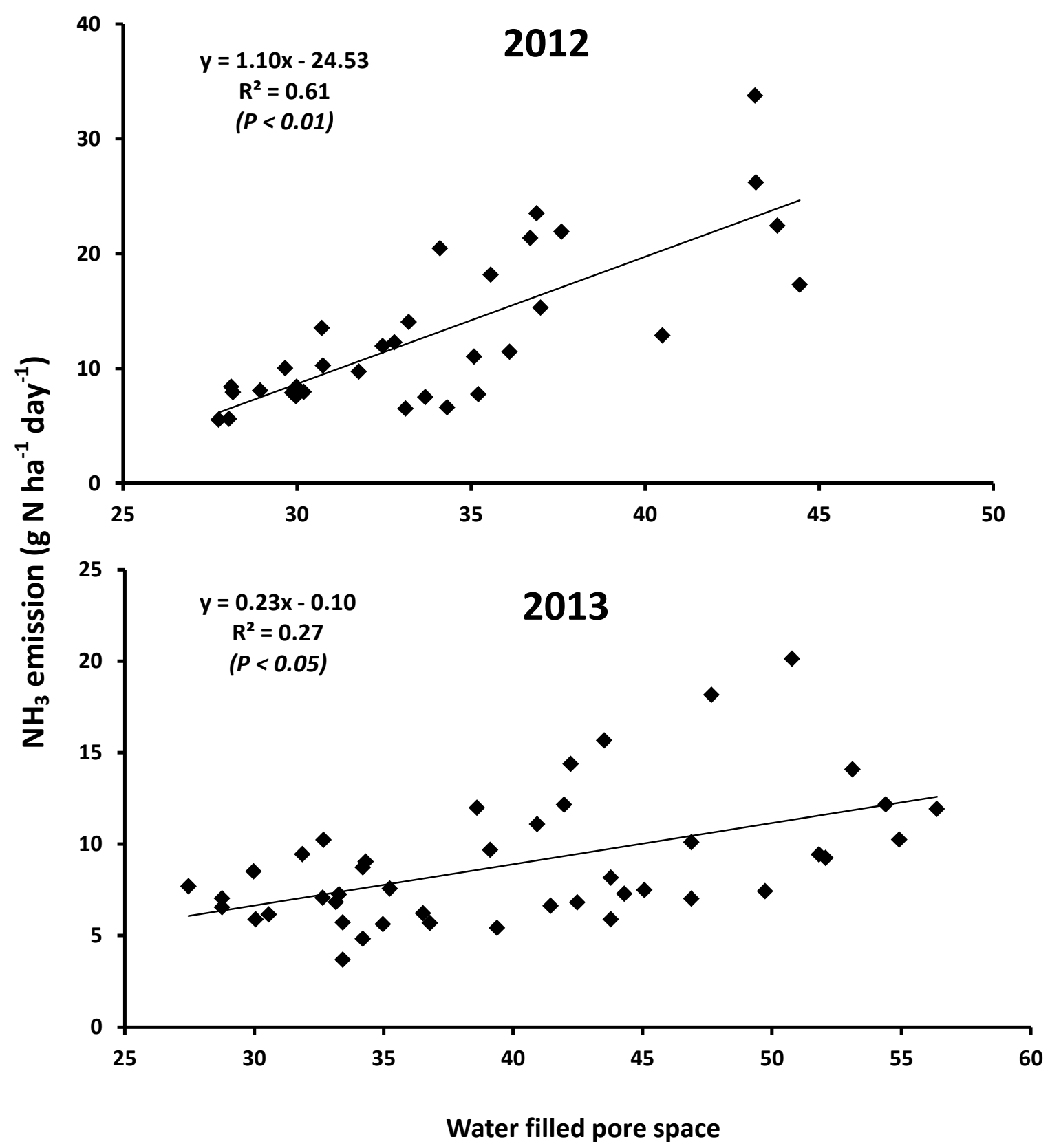

Fig 6. Relation between daily ammonia losses and water filled pore space (\%) in 2012 and 2013 
Graphical Abstract (for review)
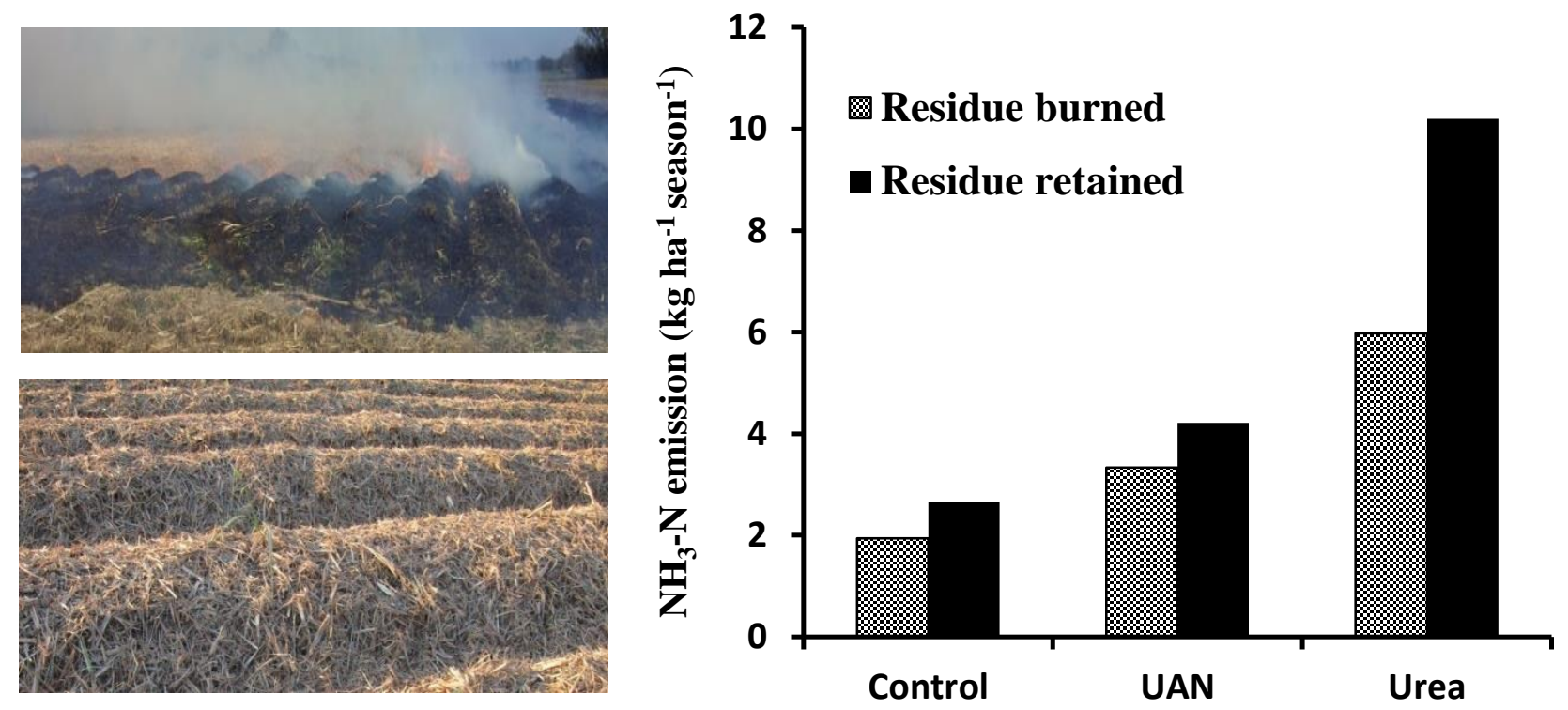

Contro

$$
\text { Urea }
$$

